\title{
Physicians' intention to leave direct patient care: an integrative review
}

\author{
Christiane Degen*, Jian Li and Peter Angerer
}

\begin{abstract}
Background: In light of the growing shortage of physicians worldwide, the problem of physicians who intend to leave direct patient care has become more acute, particularly in terms of quality of care and health-care costs.

Methods: A literature search was carried out following Cooper's five-stage model for conducting an integrative literature review. Database searches were made in MEDLINE, PsycINFO and Web of Science in May 2014.

Results: A total of 17 studies from five countries were identified and the study results synthesized. Measures and percentages of physicians' intention to leave varied between the studies. Variables associated with intention to leave were demographics, with age- and gender-specific findings, family or personal domain, working time and psychosocial working conditions, job-related well-being and other career-related aspects. Gender differences were identified in several risk clusters. Factors such as long working hours and work-family conflict were particularly relevant for female physicians' intention to leave.

Conclusions: Health-care managers and policy-makers should take action to improve physicians' working hours and psychosocial working conditions in order to prevent a high rate of intention to leave and limit the number of physicians actually leaving direct patient care. Further research is needed on gender-specific needs in the workplace, the connection between intention to leave and actually leaving and measures of intention to leave as well as using qualitative methods to gain a deeper understanding and developing validated questionnaires.
\end{abstract}

Keywords: Intention to leave direct patient care, Physicians, Medical profession, Integrative review, Physician shortage

\section{Background}

Losing physicians from the workforce is a problem in many countries and particularly in those where there is already a physician shortage $[1,2]$. Research on the physician shortage has found that the causes in many countries are the poor geographical distribution of physicians $[3,4]$, a mismatch between growing medical demands (for example, population ageing, which increases utilization of medical services [5]) and restricted supply (for example, intake rates to medical schools $[4,6]$ ) and retaining physicians in patient care until retirement age $[4,7,8]$. This study focuses on retention. Studies have found that the process of losing physicians from the workforce starts directly after graduation and persists throughout the physician career [9-11]. The problem is

\footnotetext{
*Correspondence: christiane.degen@uni-duesseldorf.de

Institute of Occupational Medicine and Social Medicine, Centre for Health and Society, Faculty of Medicine, University of Düsseldorf, Düsseldorf, Germany
}

(c) 2015 Degen et al. Open Access This article is distributed under the terms of the Creative Commons Attribution 4.0 International License (http://creativecommons.org/licenses/by/4.0/), which permits unrestricted use, distribution, and reproduction in any medium, provided you give appropriate credit to the original author(s) and the source, provide a link to the Creative Commons license, and indicate if changes were made. The Creative Commons Public Domain Dedication waiver (http://creativecommons.org/publicdomain/zero/1.0/) applies to the data made available in this article, unless otherwise stated. exacerbated by an increasing proportion of female physicians working part-time during childbearing age and the fact that female physicians are less likely than their male colleagues to have extended working hours $[6,8,12]$. To prevent actual leaving, reasons for leaving must be better understood. There is a long tradition of review studies focusing mainly on organizational turnover in employees [13], registered nurses [14] and physicians [15]. Less research has been conducted in recent decades on professional or occupational turnover intent, which is the focus of this review. To date, there is little evidence about the risk factors for physicians actually leaving patient care, although one study has shown that intention to leave (ITL) is a strong precursor of actually leaving [2]. Therefore, research on ITL could help identify a high-risk group for early intervention before leaving actually occurs. 
As such, we aim to review the literature and summarize factors associated with the intention to leave direct patient care as reported by physicians. This is the first review study on this subject. Special attention is given to potential risk factors for the development of ITL and factors that can potentially be modified, such as working conditions and gender-specific workplace needs.

\section{Methods}

\section{Review design}

An integrative review was conducted according to the steps in the five-stage method recommended by Cooper [16]: formulation of the research problem, data collection, data evaluation, data analysis and presentation of the results.

\section{Search strategy and study selection}

The first author conducted the database search. Relevant literature was extracted using a search of the following databases: MEDLINE, PsycINFO and Web of Science. Search terms were combinations of "intent(ion)(s) to" and "leave/withdraw/quit", "leaving intention(s)", combinations of "leaving" and "medicine/clinical care/patient care/the medical profession" and combinations of "quitting/withdrawing" and "intention(s)". All search terms with more than 100 search results were restricted by AND (physician* OR doctor*). The search identified publications with at least one search term in the title or abstract. The earliest publication found was from 1992. As such, it was not necessary to limit the search period to select only recent publications on physician ITL direct patient care. The search covered all articles published prior to May 2014 in English or German. The references within the identified publications were also considered in order to find relevant literature not identified by the database search.

\section{Study selection criteria}

Studies were included in the review if the original research was presented, the study population comprised postgraduate physicians, the study focus was the intention to leave direct patient care and the language was English or German. All studies that focused on turnover intentions such as intention to leave the current practice [17] or intentions to quit the current employment [18] were excluded from the review since there would be no net loss of physicians in the workforce in these cases.

\section{Search outcome}

The first database search identified 539 hits (104 MEDLINE, 254 PsycINFO and 181 Web of Science), and snowballing procedures identified an additional 20 hits (Figure 1). After screening the titles and abstracts using the study selection criteria, 42 articles remained. Full-text examination of these articles reduced the number of studies included in this review to 17 . Decisions to include or exclude studies were made by the first author under the supervision of the second author.

\section{Framework for analysis}

Studies were synthesized using the following criteria: author information, sample, country, medical speciality, study design, career phase, research focus, study

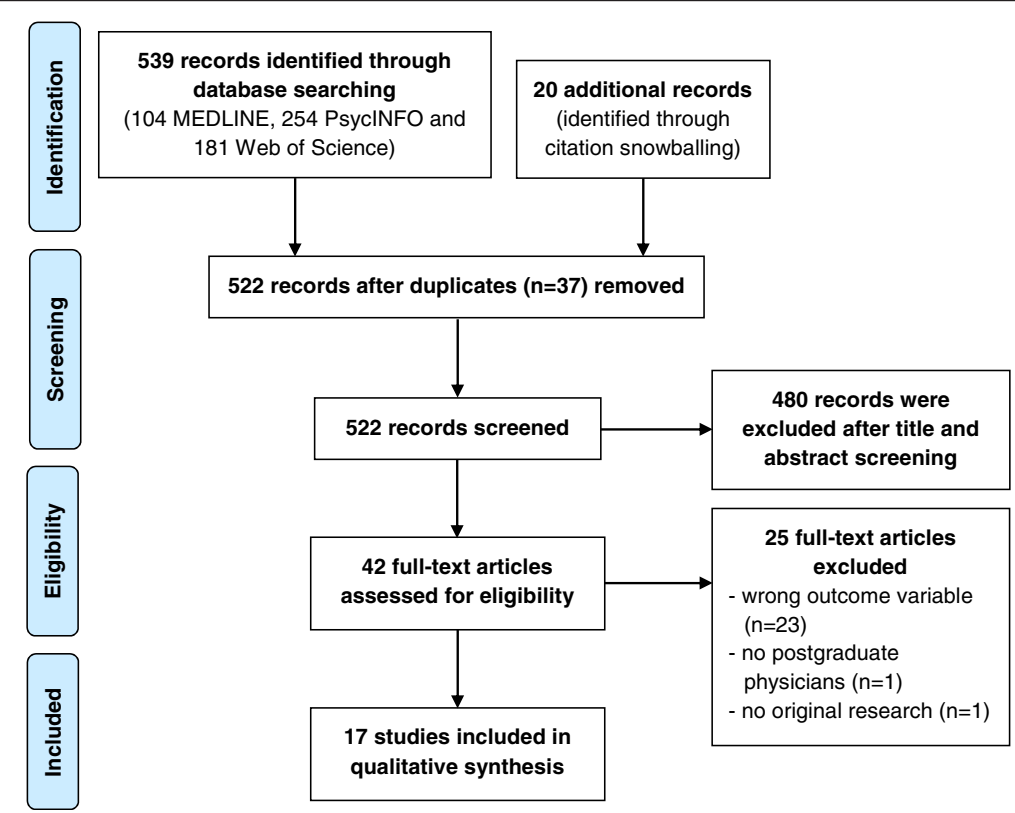

Figure 1 Flowchart on database search and study selection. 
instruments, measurement of ITL, proportion of ITL and variables associated with ITL. To allow readers to evaluate the quality of the studies [19] included in the review, we provide additional details in Table 1 (research question, response rate, sample demographic, sample size) and Table 2 (research instrument). While we identified some weaknesses in the research instruments, which stemmed from the use of non-standard, self-designed questionnaires, we decided to analyse all studies for the sake of a broader literature review.

\section{Results}

\section{Study characteristics}

The 12 cross-sectional and 5 longitudinal studies were published between 1998 and 2011 (Table 1). All studies used quantitative methods, and two included open questions on reasons behind ITL. The studies were conducted in different countries: the UK (seven studies), Germany (four), the US (three), France (two) and Finland (one). While most studies (11) investigated a wide range of specialities, 2 focused on emergency physicians, 3 on general practitioners (GPs) or family physicians, and 1 on surgical fields (surgery, gynaecology and obstetrics). All studies had mixed-gender samples, and the proportion of male physicians ranged from $40.8 \%$ to $89.9 \%$. Most studies (10) covered all career phases, while 3 studied physicians in the early career phase, 3 studied mid-career physicians and 1 studied the mid- and late-career phases. The sample sizes in the studies reviewed ranged from 296 to 2926 (Table 2).

\section{Measuring ITL and the percentage of physicians intending to leave direct patient care}

The reported percentage of physicians with ITL varied from $3.2 \%$ [20] to $53.7 \%$ [21] across the studies. Three measures were used to determine ITL: prospective measures asking physicians for the likelihood of leaving or intention to leave on a prospective time scale or until retirement (nine), retrospective measures asking for thoughts in the preceding 12 months (five) and universal measures without a time frame (three). The most commonly used prospective measure was "likelihood of leaving direct patient care within five years" (four); here, the percentage of physicians with ITL ranged from $11.8 \%$ to $22 \%$ (scores of 4 or 5 on a five-point Likert scale). The most frequently used retrospective measure was "how often during the past 12 months/ course of the past year have you thought about giving up the profession/clinical practice" (five); here, the percentages ranged from $17.4 \%$ to $25.7 \%$ (scores of 3,4 or 5 on a five-point Likert scale). Overall, the prospective percentages of physicians with ITL were slightly smaller than the retrospective percentages.

\section{Variables associated with ITL}

Many different variables are associated with ITL. Therefore, similar explanatory factors were grouped under the following general terms: demographics, family or personal domain, working time and psychosocial working conditions, job-related well-being and career-related aspects. ${ }^{\text {a }}$

\section{Demographic variables}

The studies reported significant associations of ITL with having children, ethnicity, medical speciality, age and gender. Physicians from ethnic minorities [22] and emergency physicians compared to hospital physicians [23] had a higher ITL. Female physicians working in paediatrics, anaesthesiology and surgery had lower ITL than those in internal medicine, while the same was true for male physicians in surgery and orthopaedics compared to those in internal medicine [24]. Lower ITL was also found in physicians with children under the age of 18 [22,25].

The demographic aspects of age and gender were discussed frequently in the studies. The next two paragraphs summarize these discussions.

\section{Age-specific findings}

The impact of age on ITL was examined in eight studies. Three found null association with samples of physicians in their first or second postgraduate year [24] or primarily after the age of 45 [26] or primarily before the age of 45 [23]. Five studies with age ranges from postgraduate to retirement age found mixed results. Two studies found that younger physicians had a higher ITL $[21,27]$. The relative frequency of ITL at different ages was presented in one study [21], which indicated low ITL for very young physicians, the highest ITL for those aged 33-35 and decreasing ITL for physicians after the age of 50 . Conversely, three studies indicated that older physicians had a higher ITL than those under the age of 35 [22,25,28].

\section{Gender-specific findings}

Gender-specific analyses were conducted in seven studies. Two UK studies found that female physicians were more likely than their male colleagues to intend to remain in the National Health Service (NHS) [12,29]. Another study showed that male physicians with a partner and children under the age of 16 were less likely to indicate ITL [24].

Further gender-specific findings were identified for many of the explanatory factors. We describe these in the following after the general findings for each factor.

\section{Family or personal domain}

Evidence of a connection between work-family conflict and ITL was observed in two studies. High work demands 
Table 1 Summary of study characteristics and research focus

\begin{tabular}{|c|c|c|c|c|c|}
\hline Author, year, country & Sample & Medical speciality & Design & Career phase & Research focus/question \\
\hline $\begin{array}{l}\text { Bornschein et al. } \\
2006 \text { [21], Germany }\end{array}$ & $\begin{array}{l}\text { Inpatient and outpatient care physicians } \\
\text { in Munich } \\
59 \% \text { male } \\
\text { Age: }<35=1163 \\
\quad 36-45=815 \\
\quad 46-55=321 \\
56+=136 \\
\text { Mean age: } 38\end{array}$ & Different specialities & $\begin{array}{l}N=5,461 / 2,450 \text { (RR 47\%) } \\
\text { Employed physicians } \\
\text { Cross-sectional, Quantitative }\end{array}$ & All career stages & $\begin{array}{l}\text { Assess the extent to which the German } \\
\text { law on working hours is actually } \\
\text { implemented in employed physicians }\end{array}$ \\
\hline $\begin{array}{l}\text { Davidson et al. } \\
1998 \text { [12], UK }\end{array}$ & $\begin{array}{l}\text { Physicians qualified in the NHS in } 1977 \\
\text { Mid 40s }\end{array}$ & Different specialities & $\begin{array}{l}N=3,135 / 2,398 \text { (RR 78.1\%) } \\
\text { Cross-sectional, Quantitative }\end{array}$ & Mid-career & $\begin{array}{l}\text { Determine the career destinations by } \\
1995 \text { of physicians who qualified } \\
\text { in } 1977\end{array}$ \\
\hline $\begin{array}{l}\text { Davidson et al. } \\
2001 \text { [29], UK }\end{array}$ & $\begin{array}{l}\text { Physicians qualified in the NHS in } 1974 \\
\text { Mean age: } 48\end{array}$ & Different specialities & $\begin{array}{l}N=2,217 / 1,717 \text { (RR 77.4\%) } \\
\text { Cross-sectional, Quantitative } \\
\text { (open question) }\end{array}$ & Mid-career & $\begin{array}{l}\text { Systematic information about } \\
\text { retirement intentions and factors } \\
\text { that influence them }\end{array}$ \\
\hline $\begin{array}{l}\text { Estryn-Behar et al. } \\
2011 \text { [23], France }\end{array}$ & $\begin{array}{l}\text { French hospital physicians and } \\
\text { emergency physicians } \\
57.5 \% \text { and } 62.4 \% \text { male } \\
\text { Age: } \\
<35=8.2 \% \text { and } 25 \% \\
35-44=33.8 \% \text { and } 47 \% \\
45-54=34.5 \% \text { and } 23.5 \% \\
55+=23.6 \% \text { and } 4.5 \%\end{array}$ & $\begin{array}{l}\text { Different specialities of } \\
\text { French physicians and } \\
\text { emergency physicians }\end{array}$ & $\begin{array}{l}N=3,196 \text { (RR 66\%) from this } \\
\text { a representative sample } \\
(N=1,924) \text { was randomly } \\
\text { selected and compared to } \\
538 \text { emergency physicians } \\
\text { Cross-sectional, Quantitative }\end{array}$ & All career phases & $\begin{array}{l}\text { Analysis of working conditions, } \\
\text { satisfaction and health on ITL and } \\
\text { burnout for French physicians with } \\
\text { separate analysis for emergency } \\
\text { physicians }\end{array}$ \\
\hline $\begin{array}{l}\text { Estryn-Behar et al. } \\
2011 \text { [28], France }\end{array}$ & $\begin{array}{l}\text { French hospital physicians } \\
\begin{array}{l}57.5 \% \text { male } \\
\text { Age: }<35=8.2 \% \\
\quad 35-44=33.8 \% \\
\quad 45-54=34.5 \% \\
55+=23.6 \%\end{array}\end{array}$ & Different specialities & $\begin{array}{l}N=3,196(\mathrm{RR} 66 \%) \text { from this } \\
\text { a representative sample } \\
(N=1,924) \text { was randomly selected } \\
\text { Cross-sectional, Quantitative }\end{array}$ & All career phases & $\begin{array}{l}\text { Analysis of the risk factors for burnout } \\
\text { and intention to leave the profession } \\
\text { according to gender }\end{array}$ \\
\hline $\begin{array}{l}\text { Fuss et al. } \\
2008 \text { [30], Germany }\end{array}$ & $\begin{array}{l}\text { Physicians from two university hospitals } \\
\text { in North Rhine-Westphalia } \\
60.1 \% \text { male } \\
\text { Age: }<34=126 \\
\quad 35-44=98 \\
45-54=44 \\
55+=21 \\
\text { Mean age: } 38.3\end{array}$ & Different specialties & $\begin{array}{l}N=761 / 296 \text { (RR 38.9\%) } \\
\text { Cross-sectional, Quantitative }\end{array}$ & All career phases & $\begin{array}{l}\text { Investigation of predictors for work } \\
\text { interfering with family conflict }\end{array}$ \\
\hline $\begin{array}{l}\text { Goldacre et al. } \\
1999 \text { [37], UK }\end{array}$ & $\begin{array}{l}\text { All physicians who qualified in the UK in } \\
1996 \text { and } 1993 \\
\text { About } 50 \% \text { male } \\
\text { Age: NS (junior physicians) }\end{array}$ & All specialties & $\begin{array}{l}\text { In } 1996, N=3809 / 2926 \text { (RR } 76.8 \% \text { ) } \\
\text { Longitudinal - comparison of } 1996 \\
\text { and } 1993 \text { graduates }\end{array}$ & Early career & $\begin{array}{l}\text { To report the career intentions } 1 \text { year } \\
\text { after qualification of physicians who } \\
\text { qualified in the UK in } 1996\end{array}$ \\
\hline
\end{tabular}


Table 1 Summary of study characteristics and research focus (Continued)

\begin{tabular}{|c|c|c|c|c|c|}
\hline $\begin{array}{l}\text { Hann et al. } \\
2010 \text { [2], UK }\end{array}$ & $\begin{array}{l}\text { Family physicians } \\
\text { Male: NS } \\
\text { Aged } 50 \text { and below }\end{array}$ & Family physicians & $\begin{array}{l}N=2,000 / 1,174 \text { (RR 67\%) } \\
\text { Longitudinal (5 years) - Secondary } \\
\text { analysis, Quantitative }\end{array}$ & Mid-career & $\begin{array}{l}\text { Does a family physician's stated } \\
\text { intention to leave his/her job } \\
\text { predict whether or not he/she } \\
\text { actually does leave? }\end{array}$ \\
\hline $\begin{array}{l}\text { Heponiemi et al. } \\
2009 \text { [27], Finland }\end{array}$ & $\begin{array}{l}\text { Random sample of physicians } \\
40.8 \% \text { male } \\
\text { Aged } 25 \text { to } 65 \\
\text { Mean age: } 45.9\end{array}$ & All specialties & $\begin{array}{l}N=5,000 / 2,841 \text { (RR } 57 \%) \\
\text { Final sample: } 2650 \\
\text { Cross-sectional, Quantitative }\end{array}$ & All career phases & $\begin{array}{l}\text { Examine whether job control moderates } \\
\text { the association between stress } \\
\text { indicators and intention to change } \\
\text { profession }\end{array}$ \\
\hline $\begin{array}{l}\text { von dem Knesebeck et al. } \\
2010 \text { [31], Germany }\end{array}$ & $\begin{array}{l}\text { Hospital physicians working in surgical } \\
\text { fields } \\
60.2 \% \text { male } \\
\text { Age: NS ( } 920 \text { residents and } 391 \\
\text { consultants/senior physicians) }\end{array}$ & $\begin{array}{l}\text { Surgery, gynaecology } \\
\text { and obstetrics }\end{array}$ & $\begin{array}{l}N=3,648 / 1,311 \text { (RR 53\%) } \\
\text { Nationwide survey } \\
\text { Cross-sectional, Quantitative }\end{array}$ & All career phases & $\begin{array}{l}\text { Analyses of psychosocial stress in the } \\
\text { workplace with the aid of the } \\
\text { demand-control model, the } \\
\text { effort-reward imbalance model and } \\
\text { selected additional indicators }\end{array}$ \\
\hline $\begin{array}{l}\text { Moss et al. } \\
2004 \text { [20], UK }\end{array}$ & $\begin{array}{l}\text { Graduates in } 1999 \text { at the end of the first } \\
\text { postgraduate year } \\
<50 \% \text { men } \\
\text { Age of junior physicians: NS }\end{array}$ & $\begin{array}{l}\text { Graduates from all } \\
\text { medical schools }\end{array}$ & $\begin{array}{l}N=4,221 / 2,727 \text { (RR } 64.6 \%) \\
\text { Analysed physicians }=1,326 \\
\text { Cross-sectional, Quantitative } \\
\text { (open question) }\end{array}$ & Early career & $\begin{array}{l}\text { Study reasons why junior physicians } \\
\text { trained in UK consider leaving } \\
\text { UK medicine }\end{array}$ \\
\hline $\begin{array}{l}\text { Ochsmann } \\
2012 \text { [24], Germany }\end{array}$ & $\begin{array}{l}\text { Junior physicians in Bavaria in their first or } \\
\text { second postgraduate year } \\
42 \% \text { men } \\
\text { Mean age: } 28.9\end{array}$ & Different specialities & $\begin{array}{l}N=1,494 / 792(\text { RR } 53 \%) \\
\text { Analysed physicians }=637 \\
\text { Cross-sectional, Quantitative }\end{array}$ & Early career & $\begin{array}{l}\text { Examine the association between } \\
\text { workplace factors and thinking about } \\
\text { leaving clinical care using a } \\
\text { gender-stratified approach }\end{array}$ \\
\hline $\begin{array}{l}\text { Pachulicz et al. } \\
2008 \text { [26], US }\end{array}$ & $\begin{array}{l}\text { Emergency physicians that completed } \\
\text { residency in 1979,1984, } 1988 \text { and } 1993 \\
\text { Over } 80 \% \text { men } \\
\text { Age at 2004: primarily over the age of } \\
45 \text { with } 6 \% \text { over } 65\end{array}$ & Emergency physicians & $\begin{array}{l}\text { 1,269 participants in } 2004 \\
\text { Longitudinal - three waves, Quantitative } \\
\text { ITL was measured in } 2004 \text { (T3) }\end{array}$ & $\begin{array}{l}\text { Mid-and } \\
\text { late career }\end{array}$ & $\begin{array}{l}\text { Objective and subjective career } \\
\text { successes were hypothesized to } \\
\text { mediate the relationships between } \\
\text { socio-demographic variables, human } \\
\text { capital indices, individual difference } \\
\text { variables and organizational sponsorship } \\
\text { as inputs and intention to leave } \\
\text { medicine as the output variable }\end{array}$ \\
\hline $\begin{array}{l}\text { Rittenhouse et al. } \\
2004 \text { [33], US }\end{array}$ & $\begin{array}{l}\text { Specialist physicians practising in large } \\
\text { urban counties in California } \\
89.8 \% \text { male } \\
\text { Age: }<55 \text { years }=62.8 \% \\
\quad 55-64 \text { years }=27.3 \% \\
65+\text { years }=9.9 \%\end{array}$ & Different specialities & $\begin{array}{l}N=1,492 / 978 \text { (RR 66\%) } \\
\text { Longitudinal (3 years), Quantitative }\end{array}$ & All career phases & $\begin{array}{l}\text { To validate physicians' self-reported } \\
\text { intention to leave clinical practice and } \\
\text { the Masterfile practice status variable } \\
\text { as measures of physician attrition and } \\
\text { to determine predictors of ITL and } \\
\text { actual departure from clinical practice }\end{array}$ \\
\hline $\begin{array}{l}\text { Scott et al. } \\
2006 \text { [25], UK }\end{array}$ & $\begin{array}{l}\text { Representative sample of English and } \\
\text { Scottish GPs } \\
68 \% \text { male } \\
\text { Age in \%: }<35=0.14 \\
\qquad \begin{array}{l}35-39 \\
40-44=0.19 \\
45-49=0.21 \\
50-54=0.18 \\
55-59=0.09 \\
60+=0.02\end{array}\end{array}$ & General practitioners & $\begin{array}{l}N=4,421 / 2,781 \text { (RR } 62.9 \%) \\
1,968 \text { questionnaires were } \\
\text { available for analysis (44\%). } \\
\text { Cross-sectional, Quantitative }\end{array}$ & All career phases & $\begin{array}{l}\text { Clarify the relationships between ITL, } \\
\text { overall job satisfaction, domains of job } \\
\text { satisfaction and personal and job } \\
\text { characteristics by using a structural } \\
\text { recursive model }\end{array}$ \\
\hline
\end{tabular}


Table 1 Summary of study characteristics and research focus (Continued)

\begin{tabular}{|c|c|c|c|c|c|}
\hline $\begin{array}{l}\text { Sibbald et al. } \\
2003 \text { [22], UK }\end{array}$ & 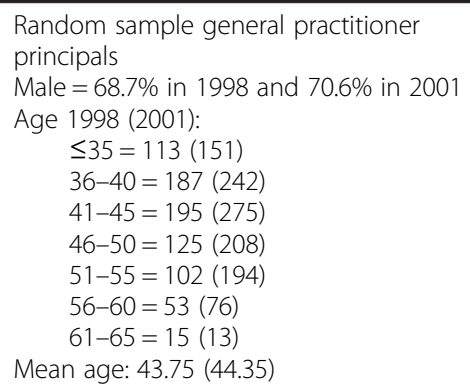 & General practitioners & $\begin{array}{l}\text { Sample 1998: 2,064/974 (RR 47\%) } \\
\text { Sample 2001: 2,000/1,332 (RR 67\%) } \\
\text { Final sample } 790 \text { in } 1998 \text { and } \\
\text { 1,159 in } 2001 \\
\text { Longitudinal, Quantitative }\end{array}$ & All career phases & $\begin{array}{l}\text { Measure GPs' intentions to quit direct } \\
\text { patient care, to assess changes } \\
\text { between } 1998 \text { and } 2000 \text { and to } \\
\text { investigate associated factors, notably } \\
\text { job satisfaction }\end{array}$ \\
\hline $\begin{array}{l}\text { Williams et al. } \\
2001 \text { [32], US }\end{array}$ & $\begin{array}{l}\text { Clinically active physicians working in } \\
\text { patient care in office or hospital } \\
\text { settings aged }<57 \text { years } \\
66.7 \% \text { male } \\
\text { Mean age: } 43.7\end{array}$ & Different specialities & $\begin{array}{l}N=5,704 / 2,325 \text { (adjusted RR 52\%) } \\
\text { Final sample 1,735 } \\
\text { Cross-sectional, Quantitative }\end{array}$ & All career phases & $\begin{array}{l}\text { Analysing a conceptual model of } \\
\text { physician stress that explores its } \\
\text { relationship with job satisfaction, } \\
\text { physical and mental health and four } \\
\text { types of withdraw intentions }\end{array}$ \\
\hline
\end{tabular}

$R R$ response rate, $N S$ not specified. 
Table 2 Research instruments, measure and percentage of physicians' intention to leave direct patient care

\begin{tabular}{lll}
\hline Author, year, country & $\begin{array}{l}\text { Sample } \\
\text { size }\end{array}$ & Questionnaires/instruments/scales \\
\hline $\begin{array}{l}\text { Bornschein et al. 2006 [21] }{ }^{c}, \\
\text { Germany }\end{array}$ & 2,450 & $\begin{array}{l}\text { Questionnaire about working hours and } \\
\text { working conditions developed by authors }\end{array}$
\end{tabular}

Davidson et al. 1998 [12] $]^{a}$ UK $\quad 2,398$

Davidson et al. 2001 [29] $]^{\mathrm{a}}$, UK

Estryn-Behar et al. 2011 [23] $]^{\text {, }}$ France

Estryn-Behar et al. $2011[28]^{b}$ France

Fuss et al. $2008[30]^{b}$, Germany

Goldacre et al. 1999 [37] $]^{\mathrm{a}}$ UK

Hann et al. 2010 [2] , UK
Questionnaire developed by authors

Questionnaire developed by authors

"Do you intend to practise in the NHS until normal retirement age?"

Five-point scale (yes-definitely to

no-definitely not)

"Do you intend to practise in the NHS until normal retirement age for your current post?" Five-point scale ("yes, definitely" to "no, definitely not"

"How often during the course of the past year have you thought about giving up the medical profession?"

Primarily over the age of 45-point scale ("never" to "every day") with scale, quality of teamwork, interpersonal relations within team, influence at work, quantitative demands, health

Questionnaire from the NEXT study group adapted for physicians; focus on burnout, work-family conflict, satisfaction with pay scale, quality of teamwork, interpersonal relations within team, influence at work, quantitative demands, health

Copenhagen Psychosocial Questionnaire (COPSOQ), work interfering with family conflict scale (WIF), items on hospital-specific work organization developed by the authors Postal questionnaire developed by authors

Data from the national survey of family physicians 2001 on ITL and job satisfaction and data from the annual census of physicians in the NHS for actually leaving

"How often during the course of the past year have you thought about giving up the medical profession?

Five-point scale ("never" to "every day")

"How often during the past 12 months have Five-point scale ("never" to "every day" transformed to a range from 0 to 100)

"Apart from temporary visits abroad, do you intend to practise medicine in the UK for the foreseeable future?"

If you did not answer "Yes, definitely", are you:

(a) considering practising medicine abroad?

(b) considering leaving medicine but remaining

in the UK?

(c) considering leaving medicine and leaving

the UK?

Five-point scale ("yes, definitely" to "no,

definitely not") care within the next 5 years"

Five-point scale ("none" to "high")
Measurement of ITL

"Do you thinking about giving up medica

practice in in- or out-patient care?"

Three-point scale ("yes", "I have thought about it", "no")

\section{Percentage of ITL}

Overall ITL $=53.7 \%$

$13.8 \%$ intended to quit their job and $39.8 \%$ had thought about quitting their job

1,714 physicians worked in the NHS $22.9 \%$ of the NHS physicians did not intend to work until normal retirement age and

$11.5 \%$ were undecided

1,427 physicians worked in the NHS: $25.2 \%$ of the NHS physicians definitely did not plan to continue until normal retirement age, 26\% would probably not and $13.9 \%$ were undecided

$21.4 \%$ of the emergency physicians considered leaving the profession with answers of "sometimes in a month" or "more often" you thought about giving up your profession?"

"Likelihood that they would leave direct patient
17.4\% of French hospital physicians considered leaving the profession with answers of "sometimes in a month" or "more often"

Mean score $=18.6$

$9.4 \%$ of the UK-based qualifiers in 1996 and $6.8 \%$ of overseas-based respondents expressed the possibility that they might leave medicine ("yes, probably" and higher)

$39(11.8 \%)$ rated the likelihood of ITL within next 5 years as "likely" or "high" 
Table 2 Research instruments, measure and percentage of physicians' intention to leave direct patient care (Continued)

Heponiemi et al. $2009[27]^{c}, \quad 2650$

Finland

Job control from Job Content Questionnaire, psychological distress from General Health Questionnaire, sleeping problems from Jenkins sleep problem scale

von dem Knesebeck et al.

$2010[31]^{b}$, Germany

Effort-reward-imbalance questionnaire, Job Content Questionnaire (JCQ), two items on the shift of stress from work to private life, two items for quality of patient care

Moss et al. $2004[20]^{c}$, UK

Questionnaire developed by authors, main question "Specifying main reasons for considering leaving"

Questionnaire developed by authors on demographic background, medical education, current workplace factors and health-related questions

American Board of Emergency Medicine (ABEM)

Longitudinal Study of Emergency Physicians (LSEP)

Survey of specialist physicians in urban California (1998); the American Medica Association (AMA) Physician Masterfile (2001); and direct ascertainment of physician practice status (2001)

Main study items: career intention, career satisfaction, practice setting, practice experience

Scott et al. $2006[25]^{\mathrm{a}}$, UK

Questionnaire developed by authors

Sibbald et al. 2003 [22] $]^{a}$, UK

National postal surveys on overall job satisfaction, intention to leave direct patien care and physicians' personal and practice characteristics

Williams et al. 2001 [32] ${ }^{\mathrm{a}}$, US 1735

Perceived stress scale, global job satisfaction, single item for physical health, mental health three-item measure (anxiety, depression and burnout)

"If it were possible would you like to change to another profession with a similar salary?"

Not specified (in the regression analysis, the TTL measure was used as an ordinal variable

Three response categories ("no", "perhaps", "yes") which represents a higher level of ITL)

"How often in the preceding 12 months they had thought of giving up their profession" Five-point scale ("never", "several times a year, ... month, ... week", to "every day")

"Considering leaving medicine but remaining in the UK" and "considering leaving medicine and the UK" were grouped to "considering leaving medicine"

Five-point scale ("yes, definitely" to "no,

definitely not")

"During the last 12 months I thought about giving up clinical practice..."

Five-point scale ("never" to "every day")

Intention to leave medicine: "Whether or not they hoped to leave medical practice for another career in the next 5 years" $(1=$ "yes", $0=$ "no")

"Three years from now, do you think that you will be:

(1) still practicing medicine and seeing patients; (2) still working in medicine but no longer seeing patients;

(3) working in a career other than medicine; (4) retired."

"Likelihood of leaving direct patient care within five years"

(1 = "none", 5 = "high")

"Likelihood of leaving direct patient care (primary or hospital) within five years" Five-point scale ("none" to "high")

Likelihood of "leaving the practice of direct patient care within 5 years"

Five-point likelihood scale (3 = "moderate")
$20.7 \%$ of the hospital physicians surveyed thought about giving up their profession at least a few times per month

42 of the 1326 physicians analysed (3.2\%) were "probably not" or "definitely not" going to continue to practise medicine

$52.3 \%$ thought about leaving clinical practice: 16 (2.5\%) "every day", 50 (7.8\%) "a few times per week", 98 (15.4\%) "a few times per month", 169 (26.5\%) "a few times per year" and 304 (47.7\%) "never".

Not specified

Intention to leave clinical practice $=8.8 \%$ $5 \%$ intended to be still working in medicine but no longer seeing patients

$3.8 \%$ intended to be working in a career other than medicine

(128\% intended to retire)

Mean score 2.15 (standard deviation 1.36)

Scores of 4 and 5 were determined as ITL Intending to quit direct patient care in the next 5 years rose from $14 \%$ in 1998 to $22 \%$ in 2001

$18.5 \%$ of the physicians expressed "moderate" or greater likelihood of leaving direct patient care 
that interfered with family duties were associated with higher ITL [30]. Of all the reasons behind ITL, 26.1\% belonged to the category "family reasons, time for leisure and other interests" and 19.6\% belonged to the category "maintaining good health and wanting a healthy retirement" [29]. Sleeping problems were also associated with higher ITL [27].

Gender-specific findings showed that female physicians were more than twice as likely as their male colleagues to cite "family reasons, time for leisure and other interests" as a cause of ITL [29]. ITL was also higher for female hospital physicians with poor sleep quality [28], male emergency physicians and male hospital physicians who worried about making mistakes $[23,28]$.

\section{Working time and psychosocial working conditions}

Four studies reported an association between factors related to working time and ITL. Physicians with oncall duties and fewer breaks were more likely to indicate ITL [21]. One major reason for ITL was long working hours [20].

Three studies reported gender-specific findings. Female physicians reported higher ITL with 50 or more working hours each week [23], weekly overtime of 5 to $10 \mathrm{~h}$ [24] and long working hours [21]. Conversely, male physicians with fewer weekend duties reported lower ITL [24].

A variety of psychosocial working conditions were associated with ITL. A high degree of job control was associated with lower ITL; this factor also mitigated the positive effects of distress and sleeping problems on ITL [27]. Low quality of teamwork [28] and little or no work-related support from colleagues and superiors [24] increased ITL. Higher ITL was associated with high psychosocial stress (measured by effort-reward imbalance and job strain) [31], non-permanent positions [21] and dissatisfaction with the ability to choose method of working [25]. More than a third of physicians (36.5\%) reported that the main reason for ITL was work-related pressure [29], while $35 \%$ cited poor working conditions in general [20].

Gender-specific results: ITL was higher for male emergency physicians with a low quality of teamwork [23], male hospital physicians reporting hostile relations with the administration [28] and men with fewer opportunities for postgraduate training [24]. Among women, ITL was higher for emergency physicians reporting monthly or more frequent harassment by superiors [23] and those with a low influence at work [23] and a lack of performance feedback [24].

\section{Job-related well-being}

Several studies reported an association between job dissatisfaction and higher ITL [2,22,25,32]. The lack of job satisfaction was also regarded as an important reason behind ITL $[20,29]$. Another study found that job satisfaction mediated the link between perceived stress and ITL [32].

Four studies investigated mental health aspects. Higher ITL was linked with a high general burnout among emergency physicians [23]; patient-related burnout among hospital physicians [28]; poorer mental health as measured by depression, anxiety and burnout [32]; and high levels of psychosocial distress [27].

Gender-specific findings on high ITL were reported for female emergency physicians with high patientrelated burnout [23] and female hospital physicians with high general burnout [28].

\section{Career-related aspects}

Links were reported between career-related aspects such as job opportunities, salary and career satisfaction and ITL. Emergency physicians with job opportunities outside the health-care sector [23] and less salary progression reported higher ITL [26].

Gender-specific results for high ITL were found for male hospital physicians with job opportunities within and outside the health sector, women with a low salary satisfaction [28] and male emergency physicians with a lower career satisfaction [26].

\section{Associations between ITL and actually leaving}

Two studies examined ITL and physicians actually leaving medical practice. A national survey of family physicians in England collected data $(N=1,174)$ on physicians' ITL within the next 5 years [2]. The prevalence of ITL at the baseline survey was $11.8 \%$, and the incidence of leaving direct patient care at the 5-year follow-up survey was $16.5 \%$. The study showed that a higher ITL was associated with a greater likelihood of actually leaving.

In a survey of specialist physicians $(N=968)$ in California, data were collected on projected working status in 3 years time [32]. At the baseline, $8.8 \%$ of physicians reported ITL, and $10.6 \%(N=101)$ of the initial sample was defined as having left clinical practice after 3 years.

\section{Discussion}

In this review, we identified 17 studies of physicians' intention to leave direct patient care from five countries and synthesized the study results. Variables associated with ITL were demographics, with age- and genderspecific findings, family or personal domain, working time and psychosocial working conditions, job-related well-being and career-related aspects. Three kinds of ITL measures were used: prospective, retrospective and universal. The share of physicians reporting ITL varied 
considerably between studies. The studies reviewed were diverse in terms of their aims, study design and instruments, making direct comparisons challenging.

\section{Critical consideration of the studies}

Country-specific effects, such as different incentives and disincentives for leaving, could explain the diverse findings on age and ITL; for example, the studies with a high ITL among young physicians were from Germany [21] and Finland [27], while the studies reporting a high ITL among older physicians were from the UK $[22,25]$ and France [28].

Different measures of ITL were used (Table 2) and different scale categories were determined for identifying ITL. Studies that determined ITL on a five-point Likert scale with scores of 3 or 4 [32] or on a three-point Likert scale with a score of 2 [21] should be interpreted with caution, as these scores included categories that indicated only a moderate ITL.

In the studies on ITL and actual leaving, the definition for actual leavers was not restricted to permanent leavers during the working-age period $[2,33]$. The results should be interpreted carefully in the context of these studies; for example, in the US study, most of the actual leavers were likely to have left due to normal retirement, as $9.9 \%$ of all physicians in the initial sample were aged 65 or over.

\section{Limitations of the review}

Search terms including "turnover" were excluded from the review because of the broad definition of turnover intentions [34] and the problem of separating turnover intention from intention to leave a job and intention to leave the profession. As our aim was to identify risk factors for intention to leave direct patient care, we decided not to include turnover intention in order to obtain rigorous results on the intention to leave direct patient care.

Decisions to include or exclude studies were made by two authors, whereas the database search was conducted by just one author. Therefore, the validity of the initial records included was not verified by a second author.

In two studies [12,29], Davidson investigated the intention to practise in the NHS until normal retirement age. In the UK, it is possible to work as a physician in the NHS or in private practice. This makes it possible for physicians to leave the NHS and switch to private practice. In the study by Davidson [29], the analysis of the reasons behind intending to leave before retirement age makes it clear that changing to private practice was not a reason for considering early retirement. Davidson [12] researched a different cohort of physicians from the same database, but the reasons behind considering early retirement are not known for these physicians. This last study by Davidson [12] was not excluded from the review, as the two cohorts differed by just 3 years. Furthermore, most physicians in the UK tend to work predominantly for the NHS and take only part-time work in private practice, if at all. This highlights that retiring from the NHS early and shifting to private practice may not be an attractive option, as this leaves too little time to amortize the additional investment and operating costs.

This shows that the differences in health-care systems, working environments and physician career systems in the countries investigated could lead to research bias. Further research is needed for a systematic examination of the prevailing conditions in each of these countries to reduce this potential bias. Another limitation concerns the small number of countries (Germany, the UK, France, Finland and the US) included in this review and the absence of low- and middle-income countries. This is partly due to the requirement that articles be in English or German, which introduced language bias.

\section{Recommendations for future research}

Unfortunately, we were unable to identify a relevant study that used qualitative methods to conduct an indepth analysis of the personal perspectives of and context behind physicians with ITL [35]. In-depth qualitative analysis could provide an overall picture of reasons behind ITL and lead to the development of a standard and rigorously psychometrically tested instrument for this research topic. Most of the studies reviewed used self-developed instruments.

Secondly, attention should be paid to how ITL is measured. It is not clear which kind of ITL measure has better explanatory power when it comes to linking risk factors and actual leaving. This methodology decision to use a prospective, retrospective or universal ITL measure is an issue for further research.

Thirdly, studies in the review had diverse aims and study designs, resulting in different sets of variables being considered in this analysis. Therefore, no single study included all of the job and personal variables that have been attributed to ITL. To present the results of similar factors together, we grouped the key findings into several categories (see the "Results" section above). In reality, all of these factors are correlated and are difficult to differentiate from each other. According to earlier findings [25], overall job satisfaction combined with job and personal characteristics was better able to predict the outcome than any single variable set. In future, a wide range of all relevant predictors should be considered in ITL analyses.

Finally, gender-specific analyses were conducted in seven studies and revealed that men and women often had different risk factors under similar circumstances; 
for example, in terms of psychosocial working conditions, higher ITL was most closely associated with a low quality of teamwork for men and a low influence at work for women. This makes it clear that men and women have different workplace needs. Deeper exploration of gender differences is warranted on this topic.

\section{Conclusions}

This integrative review provides an overview of postgraduate physicians' intentions to leave direct patient care. Early intervention on risk factors for ITL could prevent physicians from actually leaving. Based on the findings of this current review, starting points for intervention could focus on work-family conflict $[29,30]$, especially for women [29]. Factors related to working time also appear to be important and, again, particularly for women $[21,23,24]$. Health-care managers and policymakers should consider working time and work-family conflict as priorities when it comes to retaining physicians. These issues become even more critical as female physicians form an increasingly large share of the physician workforce [4-6]. There is also much evidence to indicate that job stress caused by adverse psychosocial working conditions increases ITL. Health-care managers, hospital administrators and policy-makers could address this ITL driver by improving psychosocial working conditions for the medical profession. The success of such interventions has been observed with long-term effectiveness for a wide range of psychosocial work factors and well-being among health-care professionals [36].

\section{Endnotes}

${ }^{\mathrm{a}}$ Rittenhouse et al. [33] include retirement intentions in the ITL outcome in their causal analyses (Table 2, ITL $=$ categories 2, 3 and 4). Therefore, these results are not included in this section of our review.

\section{Competing interests}

The authors declare that they have no competing interests.

\begin{abstract}
Authors' contributions
$C D$ conceived the original idea for the research and conducted the initial article search, identification and analysis. CD also wrote the review and drafted consecutive versions of the paper after receiving comments from co-authors. $J$ supervised and checked the article identification process and analysis and helped with revisions and final redrafting. PA contributed to the study conception and design, supervised the research and commented on consecutive drafts of the paper. All authors approved the final version for publication.
\end{abstract}

\section{Acknowledgements}

The authors gratefully acknowledge Frederike Preußer for her support at the beginning of this research project.

Received: 15 October 2014 Accepted: 18 August 2015

Published online: 08 September 2015

\section{References}

*Studies selected for the review

1. Virtanen $P$, Oksanen $T$, Kivimäki M, Virtanen $M$, Pentti J, Vahtera J. Work stress and health in primary health care physicians and hospital physicians. Occup Environ Med. 2008;65(5):364-6.

2. Hann M, Reeves D, Sibbald B. Relationships between job satisfaction, intentions to leave family practice and actually leaving among family physicians in England. Eur J Public Health. 2010;21(4):499-503. *.

3. Chan BTB. From perceived surplus to perceived shortage: what happened to Canada's physician workforce in the 1990s? Canadian Institute for Health Information: Ottawa; 2002.

4. Simoens S, Hurst J: The supply of physician services in OECD countries. In: OECD health working papers: Paris; OECD Publishing; 2006.

5. Kopetsch T. Dem deutschen Gesundheitswesen gehen die Ärzte aus. 5th ed. Berlin: Bundesärztekammer und Kassenärztliche Bundesvereinigung; 2010.

6. Blum K, Löffert S. Ärztemangel im Krankenhaus - Ausmaß, Ursachen, Gegenmaßnahmen. Deutsches Krankenhausinstitut: Düsseldorf; 2010.

7. Joyce CM, MCNeil JJ, Stoelwinder JU. More doctors, but not enough: Australian medical workforce supply 2001-2012. Med J Aust. 2006;184(9):441-6.

8. Cooper R: The US physician workforce: where do we stand? In: OECD health working papers: Paris; OECD Publishing; 2008.

9. Goldacre MJ, Lambert TW, Davidson JM. Loss of British-trained doctors from the medical workforce in Great Britain. Med Educ. 2001;35(4):337-44.

10. BMGS. Gutachten zum Ausstieg aus der kurativen ärztlichen Berufstätigkeit in Deutschland. Hamburg: Bundesministerium für Gesundheit und Soziale Sicherung (BMGS); 2004.

11. Powell PT, Nakata DA. Can earnings decline cause a retirement flight of physicians? Financial compensation and the decision to stay in practice. Med Care Res Rev. 2001;58(3):361-78.

12. Davidson JM, Lambert TW, Goldacre MJ. Career pathways and destinations 18 years on among doctors who qualified in the United Kingdom in 1977: postal questionnaire survey. BMJ. 1998;317(7170):1425-8. *.

13. Holtom BC, Mitchell TR, Lee TW, Eberly MB. Turnover and retention research: a glance at the past, a closer review of the present, and a venture into the future. Acad Manag Ann. 2008;2(1):231-74.

14. Gilmartin MJ. Thirty years of nursing turnover research: looking back to move forward. Med Care Res Rev. 2013;70(1):3-28.

15. Misra-Hebert AD, Kay R, Stoller JK. A review of physician turnover: rates, causes, and consequences. Am J Med Qual. 2004;19(2):56-66.

16. Cooper HM. Synthesizing research: a guide for literature reviews. 3rd ed. Thousand Oaks, CA: Sage Publications; 1998.

17. Linzer M, Baier Manwell L, Mundt M, Williams E, Maguire A, McMurrey J, et al.: Organizational climate, stress, and error in primary care: The MEMO study. In: Advances in patient safety: from research to implementation (Volume 1: Research findings). Edited by Henriksen K, Battles JB, Marks ES, Lewin DI. Rockville (MD), Agency for Healthcare Research and Quality (US); 2005.

18. Walsh J. Gender, the work-life interface and wellbeing: a study of hospital doctors. Gender Work Organ. 2013;20(4):439-53.

19. Whittemore R, Knafl K. The integrative review: updated methodology. J Adv Nurs. 2005;52(5):546-53.

20. Moss PJ, Lambert TW, Goldacre MJ, Lee P. Reasons for considering leaving UK medicine: questionnaire study of junior doctors' comments. BMJ. 2004;329(7477):126. *

21. Bornschein S, Erbas B, Borelli S, Emminger C, Hesse J, Pilz J, et al. Arbeitszeit und Arbeitszufriedenheit angestellter und beamteter Ärzte in München. Gesundheitswesen. 2006;68(08/09):535-44. *

22. Sibbald B, Bojke C, Gravelle H. National survey of job satisfaction and retirement intentions among general practitioners in England. BMJ. 2003;326(7379):22. *

23. Estryn-Behar M, Doppia MA, Guetarni K, Fry C, Machet G, Pelloux P, et al. Emergency physicians accumulate more stress factors than other physicians-results from the French SESMAT study. Emerg Med J. 2011;28(5):397-410. *

24. Ochsmann EB. Thinking about giving up clinical practice? A genderstratified approach to understanding junior doctors' choices. Acad Med. 2012;87(1):91-7. *.

25. Scott A, Gravelle H, Simoens S, Bojke C, Sibbald B. Job satisfaction and quitting intentions: a structural model of British general practitioners. Brit J Ind Relat. 2006;44(3):519-40. * 
26. Pachulicz S, Schmitt N, Kuljanin G. A model of career success: a longitudinal study of emergency physicians. J Vocat Behav. 2008;73(2):242-53. *.

27. Heponiemi T, Kouvonen A, Vanska J, Halila H, Sinervo T, Kivimaki M, et al. The association of distress and sleeping problems with physicians' intentions to change profession: the moderating effect of job control. J Occup Health Psychol. 2009;14(4):365-73. *

28. Estryn-Behar M, Fry C, Guetarni K, Aune I, Machet G, Doppia MA, et al. Work week duration, work-family balance and difficulties encountered by female and male physicians: results from the French SESMAT study. Work. 2011:40(1):83-100. *

29. Davidson JM, Lambert TW, Parkhouse J, Evans J, Goldacre MJ. Retirement intentions of doctors who qualified in the United Kingdom in 1974: postal questionnaire survey. J Public Health Med. 2001;23(4):323-8. * .

30. Fuss I, Nubling M, Hasselhorn HM, Schwappach D, Rieger MA. Working conditions and work-family conflict in German hospital physicians: psychosocial and organisational predictors and consequences. BMC Public Health. 2008:8:353. *

31. von dem Knesebeck O, Klein J, Frie KG, Blum K, Siegrist J. Psychosocial stress among hospital doctors in surgical fields. Dtsch Arztebl Int. 2010;107(14):248-53. *

32. Williams ES, Konrad TR, Scheckler WE, Pathman DE, Linzer M, McMurray JE, et al. Understanding physicians' intentions to withdraw from practice: the role of job satisfaction, job stress, mental and physical health. Health Care Manage R. 2001;26(1):7-19. *

33. Rittenhouse DR, Mertz E, Keane D, Grumbach K. No exit: an evaluation of measures of physician attrition. Health Serv Res. 2004;39(5):1571-88. *

34. Flinkman $M$. Young registered nurses' intent to leave the profession in Finland - a mixed-method study. Turku: Dissertation University of Turku; 2014.

35. Creswell JW, Plano VL. Designing and conducting mixed methods research. 2nd ed. Thousand Oaks, CA: SAGE Publications; 2011.

36. Bourbonnais R, Brisson C, Vézina M. Long-term effects of an intervention on psychosocial work factors among healthcare professionals in a hospital setting. Occup Environ Med. 2011;68(7):479-86.

37. Goldacre MJ, Davidson JM, Lambert TW. Career choices at the end of the pre-registration year of doctors who qualified in the United Kingdom in 1996. Med Educ. 1999;33(12):882-9. *.

\section{Submit your next manuscript to BioMed Central and take full advantage of:}

- Convenient online submission

- Thorough peer review

- No space constraints or color figure charges

- Immediate publication on acceptance

- Inclusion in PubMed, CAS, Scopus and Google Scholar

- Research which is freely available for redistribution 